JELTL (Journal of English Language Teaching and Linguistics) e-ISSN: 2502-6062, p-ISSN: 2503-1848

2019, Vol. 4(2)

www.jeltl.org

\title{
Fostering Students' Reading Comprehension Ability through Directed Reading Thinking Activities (DRTA) Strategy
}

\author{
Yuni Putri Utami \\ Yogyakarta State University, Indonesia \\ yuni.p.utami@gmail.com \\ Sugirin \\ Yogyakarta State University, Indonesia \\ sugirin@uny.ac.id
}

\begin{abstract}
The current curriculum school reform in Indonesia supported the students to be a critical thinker in the sense that the students become a centered of teaching instruction in the school life. This changing becomes a new demand for the teacher as an educator to facilitate their learners with teaching aids practices that adjust learners to be actively participate in the classroom. Thus, this study used Directed Reading Thinking Activities (DRTA) to reveal the effectiveness of this strategy on the students' reading comprehension teaching. A quasiexperimental research design with pretest and posttest was used in this study. Two classes were randomly selected as the sample of this research. They are class $8 C$ which used Directed Reading Activities (DRA) as the control group, while class $8 H$ becomes the experimental group which used Directed Reading Thinking Activities (DRTA). Independent and dependent (paired) sample t-tests were used to analyze the data. The research finding showed: 1) there were no significant differences of posttest score among the students taught by using DRTA and those taught by using DRA strategy in reading comprehension teaching, 2) there were significant effects of using DRTA in reading comprehension teaching for grade eight students. DRTA strategy was believed to give more contribution (82\%) than DRA strategy which contributed only $77 \%$. In conclusion, DRTA was effective strategy in reading comprehension teaching.
\end{abstract}

Keywords: DRTA, DRA, teaching reading comprehension

JELTL (Journal of English Language Teaching and Linguistics), 4(2), 2019 
Yuni Putri Utami \& Sugirin

\section{INTRODUCTION}

Nowadays, thinking skills becomes a new demand in modern language educators and get important role in our new curricula. Thinking skills are necessity for learning a language however English language teachers rarely give higher order thinking instruction to their students (Anil, 2015). It indicates that some educators supposed that their students have already better intellectual abilities. Unfortunately, in reality the students have difficulties to comprehend the text even unable to think deeply and most of the time was spent to questions during the learning process in the class. However, most of the questions were in the LOT level and teacher did not ask their students with HOT questions. Concerning to this, Feng (2013) emphasized that engaging students with higher order thinking questions was teacher's duty as making sure that the students was the centered of teaching and learning process. In short, drilling students to generate questions during reading have believed to be useful strategy to make a sense of the text (Afzali, 2012). In regard to this, reading for students $21^{\text {st }}$ century becomes challenging since information spread rapidly through social media and it was not an easy matter to make a sense all those information.

In line with above explanation, Zohar \& Dori (2003) revealed that fostering students' thinking skills is regarded as an important educational goal, whereas teachers continually assert that a high achieving student was able to deal with HOT questions while the low achieving students is assumed to be unable to deal with such task. After all, basically, it is necessary for all students because thinking skills can differentiate the difficulty's level (easy to hard), thinking level (LOT to HOT), and managed each of it independently (Brookhart, 2010).

Furthermore, Aloqaili (2012) explained that theoretically, reading and thinking was well demonstrated. As one of the four skills, reading becomes an importance part for educated society (Roe \& Smith, 2012). It is a literacy skill that transfers a fundamental contribution to cognitive development. A reading skill is necessity for students to get information, to involve actively in the learning process, and to accomplish the given assignments. Reading activity is not an easy matter since the students have to deal with new vocabularies, language features, and generic structures of the text to understand the content of the text. This is a complex activity and needs high focus and concentration.

Regardless the explanation above, the data from the Organisation for Economic Cooperation and Development (OECD) proved that Indonesian learners' performance in Programme for International Students Assessment (PISA 2015) was lower than Thailand, (56) and Indonesian' ranked at 64 from 72 countries all over the world. Indeed, in the PIRLS (Progress in International Reading Literacy Study) supported the demand for reading instruction practices purposed at managing the difficulties in language and reading in both foundation particularly comprehension. As a result, reading becomes the main issue in Indonesian context that highly needed to support both in the school life and real life.

The effectiveness of DRTA strategy has been investigated in some researches on distinctive contexts and scopes, e.g. (Augustine, Suparman, \& Mahpul, 2019; Andriani, 2017; Faisal \& Lova, 2018; Hasanah, 2016; Lubis, 2018; Sari, 2017). According to Augustine et al., (2019) DRTA was the three stages of comprehension: questioning, predicting, and confirming or refuting, in order to assist student for reading. In addition, 
Andriani (2017) revealed that the purpose of DRTA was fostering students to be considerate and critical reader. Meanwhile, Sari (2017) argued that the activity in DRTA also can assist students to comprehend the text by breaking the segment and predicting the next. Yet, the effectiveness of DRTA strategy especially to foster the students reading comprehension was challenging to be explored. In regard to this, the effectiveness of DRTA strategy in reading comprehension became the main focus in this study.

\section{LITERATURE REVIEW}

There are four skills in English that should be accomplished by students, and reading becomes one of the skills that are substantial and complex for educated society. Because the students have to make a sense of the text since the reading tasks became more complex as the student moves to the higher grades. Besides, students should pass the national examination in which English subject becomes one of the four subjects to be tested in the national examination. Students can enlarge new vocabularies, and gain some information and knowledge as well as to exercise student's thinking skill through reading activities. In addition, Harmer (2001) defines reading as a receptive skill that required other skills to be accomplished. It was important for reader to engage their background knowledge as called the process of comprehension and deploy a scope of receptive skill that will decide by their purpose of reading. When reader understanding a piece of discourse means that they demanded to comprehend more than just knowing the language because to make a sense of text, it was important to have pre-existence knowledge called schema (Brown, 2004).

However, Richards \& Schmidt (2002) asserted that students did not need to comprehend the content of the text when they did oral reading because generally, oral reading is one way to help student with fluency. It was similar to Brown (2001) that affirmed comprehension was not the merely goal of reading. Therefore, comprehension and reading were two different things. As Jacobson \& Ianiro (2007) and Crawford et al., (2005) reveal that the activity of making sense and understanding the content of the text was called comprehension. In short, in this context, comprehension is the end goal of reading. People can set up the purpose of reading, integrate unknown facts and contrast the information with their prior knowledge.

The one who can use the context to support them read an unfamiliar word prove that they are attempting to make a sense of what they read. They are mindful of the literal meaning of the text. As Browne (2001) argued that comprehension was defined as an actively engaging with texts. It includes determining the hidden meaning as well as what is obvious. Figuring out closely at how texts have been written by using their knowledge of language, and using experience of the subject matter. Associating the idea of the passage and generating the author's proficiency as a language user and on particular knowledge assist people to make acquainted predictions about any unfamiliar words.

Furthermore, nowadays, reading is a must in which information spread rapidly through internet, in both printed and electronic media since they have to make sense of the information and clarify those all information essential to be used in their real life. By contrast, in the school life, reading became one of the basic attainments in language teaching that claimed some assisting component that set up reading becomes a detail activity. Reading as a school subject, specifically reading in the English classroom, explicitly will be more 


\section{Yuni Putri Utami \& Sugirin}

challenging in contrast with reading activity in Indonesian classroom. Some elements such as the inadequateness of students' English vocabulary mastery, the inadequateness of students in deconstructing the text, and the inadequateness of students' reading comprehension have to be taken into account because it became a problem in reading class. Besides, in school life, reading confirms much of attention since the skill of reading becomes the one to be tested in the national examination.

Moreover, the current trend of the national examination items type changes into higher order thinking items. These items related to Bloom's Taxonomy level involving the attainment of analyzing, evaluating, and creating. Consequently, students should response the items in domains of analyze, evaluate, and create. The consequence of elaborating thinking skill is affiliated to the current curriculum 2013 which apply scientific approach. This approach purposed at evolving students' critical thinking. Thus to keep up with the trend of the new curriculum, it is important for educators to enhance students' thinking skill particularly in reading comprehension teaching.

As a result, teachers nowadays are requested to remodeling their exercises to assist reading for higher order thinking. They are required to dispute them not merely to remember, but also to request, explore, generate, figure out, clarify, and argue the class substance. According to Crawford et al., (2005) this matter deals with the learning completely aimed that students enable to consider about what have been learned, implement it practically or as beyond knowledge, and enable to remain to independent learner.

In this case, attaining a reading skill appears to be more complex for both teacher and student. The teacher should be creative in choosing the technique and strategies for teaching reading particularly in presenting reading material to gain comprehension on it. Because of this fact, it is necessary to adjust students' reading comprehension activity in the classroom with thinking skill. As Brookhart (2010) and Chaffee (2012) asserted that empowering students with thinking skill will improve students to be a critical thinker, to be a reflected student's, and to be a problem solver. Moreover thinking skill can assist students to comprehend the text, to clarify the text and to make a sense the meaning from the text and to draw conclusion.

One of the strategies that should be considered to foster the students' reading comprehension called DRTA (Directed Reading Thinking Activities). This strategy inspires students to be a better reader and raises thinking skill that will present to increase the purpose of learning English in an effective way to enhance the reading skill. Russell (1969) was designed DRTA strategy to promote the students to make a sense of the text during the activity of reading. The stage of DRTA prompts students to read the text, and then stop to argue and or review the foreknowledge and continue to generate the new one for further reading (El-Koumy, 2006). Additionally, DRTA, particularly creating predictions, assists students focusing their awareness on the passage and promotes them to reading for understanding (Almasi, 2003).

DRTA was said to be successful if it is accurately administered in the school, and can assist to determine the process of a forceful establishment in "study-reading." This strategy will be beneficial for students since the new demand on our new curricula focusing on thinking skill (Richardson \& Morgan, 2009). It was believed DRTA strategy was beneficial 
to foster the students in comprehension the text, however, some factors may become disbenefit of this strategy if the students have been known or heard the text given and uncontrolled classroom management (Lubis, 2018). Therefore, it was suggested that the given materials was new information for students since the students' participation toward the materials was become the main point of DRTA strategy (Faisal \& Lova, 2018).

Thus, to encourage students to enhance their reading ability with promotes thinking skills, DRTA strategy was chosen as instructional strategies to be implemented in the classroom. Three steps of DRTA instructions called: predict, read, and confirm to support predictions or disconfirm the predictions. As Jonson (2006) explained that in the predicting stage, the teacher provides students with some activities that demonstrated the purpose of reading segment. In the reading stage, students start to read and keep up reading until they have finished reading and then at the stop point, they respond to some questions given by the teacher. In the last stage, the teacher asked students to create prediction about the next paragraph, to analyze the personal connection and to express the students' feeling about the story. Additionally, Hasanah (2016) mentioned that in general, the stages of DRTA was to purpose in enhancing the students to questions, hoping that they become a critical reader, and then fostering them to be thoughtful in predicting the text meaning not only the literal meaning but also the implied meaning of the text.

Unlike DRTA, Roe \& Smith (2012) defined DRA as strategy of teaching to foster the students' reading ability. Theoretically, DRA process was adequately similar to DRTA in term of silent reading activity under instruction of the teacher (Crawford et al., 2005). However, Manzo (1995) revealed that DRA strategy has been dispraised for its long steps and too long to be administered. Moreover, DRA was claimed to exclusively applicable for group instruction with traditional basal reader material (Zohar \& Dori, 2003). Hutapea \& Situmeang (2019) clarified that the process of DRA was pre-reading, during reading, and after reading. Teacher played important role in this activity as she or he asked the students to do silent reading, raised the questions for them, and guided them to discuss the text together. In other words, DRA strategy was teacher centered activity while DRTA activities was students centered since in the DRTA, teacher provides less support comprehension compared to DRA. Besides, the questions carried out were not specific and DRTA was aimed to enhance the students to create their own predictions (Crawford et al., 2005). To sum up, the DRTA strategy is supposed to enhance the students of reading comprehension ability and to gain the positive effect of classroom teaching process as well as to engage students to be independent reader.

\section{RESEARCH METHODS}

This study employed a quasi-experimental research with pretest and posttest nonequivalent group design since both the two groups were not equivalent. To get the equivalency of the groups, try out test was applied. Creswell (2014) stated that in this type of design, the two groups (experimental group A and control group B) were chosen outside of random assignment. In addition, Creswell (2012) added that figuring the cause and effect among variables become one of the goal of the experimental research. In short, this research aimed to find out the effectiveness of DRTA strategy in reading comprehension teaching for grade eight students.

JELTL (Journal of English Language Teaching and Linguistics), 4(2), 2019 


\section{Yuni Putri Utami \& Sugirin}

This research was conducted for about nine meeting (4-5 weeks) and the steps of the research were as follows: pre-survey, pre-experiment, instrument validation, giving the treatment (during experiment), data analysis and data interpretation (after experiment).

\subsection{Population and Sample}

Lodico (2010) defines the population as the subject of the research while sample is the small group being observed during the research. The research population was all the grade eight students from class 8A to $8 \mathrm{H}$ of State Junior High School 1 Yogyakarta while the sample of this study was class 8C (control group) and 8H (experimental group). Finally, the sample used in this research was 66 students which were involved 33 students from control group and 33 students from experimental group. A volunteered teacher was administered to implement the DRTA strategy.

\subsection{Instruments}

The data were collected through test, including pretest and posttest. The instrument was 30 items of multiple choice of reading comprehension tests with 4 optional answers covering the materials in regard to the core competence and basic competence of the 2013 curriculum. The pretest was conducted before giving the treatment in order to know the students' reading comprehension capability while the posttest was given after the treatment was administered to know the students' reading comprehension achievement. Both of the tests have been validated by expert judgment.

\subsection{Data Analysis}

Descriptive and inferential statistics were used to analyze the data. Independent and dependent (paired) sample t-tests were used to response the questions of the research:

1. Are there any significant differences in the students' reading comprehension achievement among the students taught by using DRTA and those taught by using DRA strategy?

2. Are there any significant effects of using DRTA strategy in reading comprehension for grade eight students?

The independent variable was DRTA and DRA strategy while the dependent variable was the students' reading ability scores.

\section{FINDINGS}

The finding was analyzed statistically through descriptive and inferential statistics. The descriptive analysis results have been showed in Table 1. While inferential statistics data were analyzed through independent sample t-test and a paired sample t-test. The data were presented in Table 2. 
Table 1. The Results of Descriptive Statistics

\begin{tabular}{lllll}
\hline & N & Sum & Mean & SD \\
\hline Pretest Experiment & 33 & 1926.67 & 58.3839 & 10.86 .865 \\
Pretest Control & 33 & 1856.68 & 56.2387 & 8.52924 \\
Posttest Experiment & 33 & 2246.67 & 68.0809 & 9.61231 \\
Posttest Control & 33 & 1856.68 & 67.2730 & 7.42846 \\
Valid N & 33 & & & \\
\hline
\end{tabular}

Regarding to Table 1, the table showed the differences in the pretest and posttest score of the two groups. After the treatment, the posttest scores of each groups gained enough satisfying result with the mean score of 68.08 and 67.27 separately. The inferential statistics was used to analyze the research hypotheses that were presented as follows:

\section{The $1^{\text {st }}$ Hypothesis} follows:

The inferential statistics procedure was analyzed through t-test and was carried out as

Ha1: There were significant differences on the students' reading comprehension achievement among the students' taught by using DRTA and those taught using DRA.

Table 2. The Pretest Results of Inferential Statistics

\begin{tabular}{llllllll}
\hline Subject & R.G & Mean & SD & N & Df & T & Sig. (2-tailed) \\
\hline Pretest & EG & 58.3839 & 10.86 .865 & 33 & 64 & .882 & .381 \\
& CG & 56.2387 & 8.52924 & 33 & & & \\
\hline P $>0.05$ & &
\end{tabular}

$\mathrm{P}>0.05$

However, the result of independent t-test demonstrated that there were no significant differences in reading comprehension pretest among the two groups since the sig. value (pvalue) was higher than the sig. level $(0.38>0.05)$.

In conclusion, the alternative hypothesis was rejected while the null hypothesis was accepted. In short, "There were no significant differences in the students' pretest mean score between the experimental group and control group."

\section{The $2^{\text {nd }}$ Hypothesis}

The inferential statistics procedure was established by analyzing the t-test and the result was presented as follows:

Ha2: There were significant differences on the students' reading comprehension achievement among students taught by using DRTA and those taught by using DRA.

Table 3. The Posttest Result of Inferential Statistics

\begin{tabular}{llllllll}
\hline Subject & R.G & Mean & SD & N & Df & T & Sig. (2-tailed) \\
\hline Posttest & EG & 68.0809 & 9.61231 & 33 & 64 & .382 & .704 \\
& CG & 67.2730 & 7.42846 & 33 & & & \\
\hline
\end{tabular}

$\mathrm{P}>0.05$ 


\section{Yuni Putri Utami \& Sugirin}

Regarding to the result of independent t-test, the data showed that the sig. value (pvalue) was higher than the sig. level $(0.70>0.05)$. It meant that there were no significant differences in the students' posttest means score among the students' taught by using DRTA and those taught by using DRA.

Finally, the alternative hypothesis was rejected while the null hypothesis was accepted. To sum up, 'there were no significant differences on the students' posttest mean score among the two groups."

\section{The $3^{\text {rd }}$ Hypothesis}

The result of the $3^{\text {rd }}$ hypothesis was analyzed by using inferential statistics. The data was presented in Table 4 as follows.

Ha3: There were significant effects on the students' pretest and posttest of reading comprehension achievement in the experimental group

Table 4. The Result of Paired Sample T-test of Experimental Group

\begin{tabular}{llllllll}
\hline Subject & GS & Mean & SD & N & Df & T & Sig. (2-tailed) \\
\hline Effect & Pretest & 58.3839 & 10.86 .865 & 33 & 32 & -12.129 & .000 \\
& Posttest & 68.0809 & 9.61231 & 33 & 32 & & \\
\hline
\end{tabular}

$\mathrm{P}<0.05$

Regarding to Table 4, the result demonstrated that the sig. value (p-value) was less than the sig. level $(0.000<0.05)$. As the hypothesis alternative $(\mathrm{Ha} 3)$ was accepted it can be concluded, 'there were significant effects on the students' pretest and posttest of reading comprehension achievement in the experimental group.'

To know the percentage of significant effects of the pretest and posttest in the experimental group, the effect of eta-squared was analyzed by using below formula. The results were presented as follows:

$$
\begin{aligned}
\eta^{2} & =\frac{t^{2}}{t^{2}+n-1} \\
\eta^{2} & =\frac{(-12.129)^{2}}{(-12.129)^{2}+32-1} \\
\eta^{2} & =\frac{147.11}{147.11+31} \\
\eta^{2} & =\frac{147.11}{147.11+31} \\
\eta^{2} & =0.82
\end{aligned}
$$

Eta-squared $=\eta^{2} \times 100 \%$

Eta-squared $=0.82 \times 100 \%=82 \%$ 
The data analysis result indicated that DRTA strategy can enhance $82 \%$ students' reading comprehension ability after implementing the strategy for about 9 meetings. Therefore, it can be implied that there are significant effects on the students' pretest and posttest of reading comprehension in the experimental group.

\section{The $4^{\text {th }}$ Hypothesis}

The result of paired sample t-test of the fourth hypothesis was presented in Table 5 as follows.

Ha4: There were significant effects on the students' pretest and posttest reading comprehension in the control group.

Table 5. The Result of Paired Sample T-test of Control Group

\begin{tabular}{llllllcr}
\hline Subject & GS & Mean & SD & N & Df & T & Sig. (2-tailed) \\
\hline Effect & Pretest & 56.2387 & 8.52924 & 33 & 32 & -10.190 & .000 \\
& Posttest & 67.2730 & 7.42846 & 33 & 32 & & \\
\hline P
\end{tabular}

$\mathrm{P}<0.05$

The result of Table 5 indicated that sig. value (p-value) was less than the sig. level $(0.000<0.05)$. It meant that the null hypothesis was rejected. To sum up, 'there were significant effects on the students' pretest and posttest of reading comprehension in the control group.'

In order to know the percentage of significant effects of pretest and posttest in the control group, the effect of eta-squared was examined as follows.

$$
\begin{aligned}
& \eta^{2}=\frac{t^{2}}{t^{2}+n-1} \\
& \eta^{2}=\frac{(-10.190)^{2}}{(-10.190)^{2}+32-1} \\
& \eta^{2}=\frac{103.83}{103.83+32-1} \\
& \eta^{2}=\frac{103.83}{103.83+31} \\
& \eta^{2}=0.77 \\
& \text { Eta-squared }=\eta^{2} \times 100 \% \\
& \text { Eta-squared }=0.77 \times 100 \%=77 \%
\end{aligned}
$$

In regard to the result, DRA strategy can enhance $77 \%$ of students' reading comprehension ability after giving the treatment for about 9 meetings. Therefore, the result indicated that there are significant effects on the students' pretest and posttest of reading comprehension in the control group.

\section{DISCUSSION}

This research examined the effectiveness of DRTA in reading comprehension teaching for student's grade eight. In a theoretical way, DRTA was believed to be effective 


\section{Yuni Putri Utami \& Sugirin}

strategy to foster the students' reading comprehension. Therefore, this part purposed to highlight the findings and to verify the theories of the effectiveness of the DRTA in reading comprehension teaching.

According to Aloqaili (2012), reading is defined as a process of thinking and reasoning to set up meaning. In same way, Hassani, Rahmany, \& Babaei (2013) defined reading as a comprehending process - the competency to assimilate, classify, and to express the main idea of text without associating them with unimportant thing and those activities needed higher order thinking dealing with a problem solving process that demands cognitive. It is essential to set up meaning through combining and clarifying in order to understand the text deeply.

When a learner reads unfamiliar vocabulary, brain visualized it in light of the preexistence knowledge (Willingham, 2007). The adversity is described as the knowledge that looks applicable refers to the outward form of the sentence. Later on, the student is questionable to read the problem and consider it to outermost of the sentence - beyond the sentence. As a result, the grammatical problem is easily seen, however the implied meaning of the problem is not. Thus, people commonly failed to visualize the first problem to assist them to figure out the second. To sum up, teachers need to assist the students to visualize the idea about the topic being discussed when they are reading.

Similar to above explanation, Fahim \& Aghaalikhani (2014) have revealed that reading portrays an important function in almost every course of study. The fact that most of the students did their reading in an unfocused way, it guides to unacceptable result of their comprehension skill. The reading instruction purposes to assist learners used the text and prior knowledge to recognize written language. Adult learners are anticipated to be conscious of strategies they can use to conceive English words, syntax, and structures. The teachers perform a significant role in this part to assist learners, to implement the strategies for individual learners. People who concentrate on precise reading to destroy comprehension can be given comprehension questions as part of pre-reading activities to guide them focusing on the understanding of the meaningful meanings in the texts they read. While, readers who did not pay more attention to accuracy in reading can engage in activities that promote accurate letter and word distinction, such as pre-reading exercises.

The preliminary result of the study was in support of early studies that it was highly needed for students to be facilitated with an appropriate strategy in the classroom teaching. DRTA is the strategy that facilitate thinking skills, as Chaemsai \& Rattanavich (2016) revealed on his research that DRTA was efficient to enhance English reading comprehension contrast to the traditional alone. Similar to Yazdani \& Mojtaba (2015) research entitled 'the explicit reading thinking activity vs. guided reading strategies'. The result revealed that DRTA believed to give more significant impact rather than DRA. Moreover, Hasan (2018) also asserted on his finding research that DRTA and DRA have significant impact on the students of reading comprehension however there were no significant differences among them. DRTA appeared to be the same as DRA in the way students did silent reading over the teacher's instruction. The same result was found in the research conducted by Lubis (2018) that DRTA strategy was believed to give significant effect for students' reading achievement, as students with extrovert learning style have higher result compared to 
introvert one. Another research conducted by Augustine et al., (2019) was revealed the same result that DRTA had more significant positive effects after implementing DRTA strategy, indeed it assisted them to actively involved in the teaching instruction.

As the result of this research showed that there were no significant differences among the strategies, this research has the same result as the previous study mention above that DRTA strategy has more significant effects compare to the DRA strategy. Despite Crawford et al., (2005) argued that the DRTA gave less assistance for comprehension and the questions bring about were less detail since DRTA assisted students to create their own prediction, DRTA was theoretically fruitful to enhance the students' comprehension.

To conclude, the result findings on this research was emphasized the idea that DRTA has significant impact that present great percentage on the students reading comprehension. The application of DRTA for teaching reading comprehension affected the students in evolving their skills of reading comprehension over their skills of thinking and they have positive attitude during process of teaching and learning.

\section{CONCLUSION}

According to research findings and the discussion, the result can be summarized as follows: (1) There were no significant differences between students taught using DRTA strategy and those taught by using DRA in reading comprehension teaching for grade eight students. (2) There were significant effects on the students of reading comprehension with $82 \%$ contribution after implementing the DRTA strategy. Finally, DRTA immersed students not only to comprehend the text but also to become a critical reader. Thus, it can be implied that DRTA strategy was applicable for junior high school students.

\section{REFERENCES}

Afzali, K. (2012). The impact of instructing self-questioning in reading literary texts in Sheikhbahaee University. International Journal of Linguistics, 4(2), 536-550. https://doi.org/10.5296/ijl.v4i2.1862

Almasi, J.F. \& Susan K.F. (2003). Teaching strategic processes in reading. $2^{\text {nd }}$ edition. NY: GuilfordPress.

Aloqaili, A. S. (2012). The relationship between reading comprehension and critical thinking: A theoretical study. Journal of King Saud University - Languages and Translation, 24(1), 35-41. https://doi.org/10.1016/j.jksult.2011.01.001

Andriani, D. (2017). The influence of reading comprehension achievement at the eighth grade students of SMP Muhammadiyah 1 Rawa Bening by using DRTA and KWL strategies. The Journal of English Language Studies. 02(01), 2541-5131.

Anil, B. (2015). Higher order questioning in SL classroom. The Buckingham Journal of Language and Lingustics. 8, 47-55.

Augustine, F., Suparman, U., \& Mahpul. (2019). The use of the directed reading thinking activity (drta) strategy in a reading class at senior high school krida utama central lampung. Unila Journal of English Teaching (U-JET), 8(1), 1-8.

Brookhart, S. M. (2010). How to assess higher-order thinking skills in your classroom. Alexandria, Virginia USA: ASCD.

JELTL (Journal of English Language Teaching and Linguistics), 4(2), 2019 
Yuni Putri Utami \& Sugirin

Brown, H. D. (2001). Teaching by principles, second edition. New York: Pearson Education.

Brown, H. D. (2004). Language asessment principles and classroom practices. New York: Pearson Education, Inc.

Browne, A. (2001). Developing language and literacy $3-82^{\text {nd }}$ edition. London: SAGE Publication.

Chaemsai, R., \& Rattanavich, S. (2016). The directed reading-thinking activity ( DR-TA ) and the traditional approach using tales of virtue based on his majesty the king's teaching concepts in seventh grade students' reading comprehension, Canadian Center of Science and Education, English Language Teaching, 9(9), 18-27. https://doi.org/10.5539/elt.v9n9p18

Chaffee, J. (2012). Thinking critically tenth edition. Boston: Wadsworth, Cengage Learning.

Crawford, A., Saul, W., Mathews, S. R., \& Makinster, J. (2005). Teaching and learning strategies for the thinking classroom. New York: The International Debate Education Association.

Creswell, J. W. (2012). Educational research, fourth edition. Boston: Pearson Education, Inc.

Creswell, J. W. (2014). Research design qualitative, quantitative, and mixed methods approaches fourth edition. California: SAGE Publication.

El-Koumy, A. S. A. K. (2006). The effects of directed reading thinking activity on EFL students' referential and inferential comprehension. Paper, Unpublished, Suez Canal University, Egypt.

Fahim, M., \& Aghaalikhani, H. (2014). The relationship between critical thinking and reading ability of efl university students in iran, Journal of Current Research in Science. 2(2), 240-243.

Faisal, \& Lova, S. M. (2018). The development of reading learning material based on drta strategy as an effort to build a literate generation in fifth grade (5th) of primary school, School Education Journal (SEJ). 8(2), 2407-4926.

Feng, Z. (2013). Using teacher questions to enhance efl students ' critical thinking ability, Journal of Curriculum and Teaching. 2(2), 147-153. https://doi.org/10.5430/jct.v2n2p147

Harmer, J. (2001). The practice of english language teaching, fourth edition. London: Longman.

Hasan, A. (2018). The effects of dra and dr-ta methods on students ' reading comprehension for state islamic, American Journal of Educational Research, 6(3), 281-287. https://doi.org/10.12691/education-6-3-16

Hasanah, U. (2016). Directed reading thinking activity (drta) on students' reading comprehension. Thesis. Lampung: Lampung university

Hassani, M. T., Rahmany, R., \& Babaei, M. (2013). The Relationship between Iranian EFL Learners' Critical Thinking and Reading Comprehension Performance in Journalistic Texts, Journal of Theory and Practice in Language Studies., 3(10), 1873-1878. https://doi.org/10.4304/tpls.3.10.1873-1878

Hutapea, J., \& Situmeang, L. M. (2019). Improving students ' competence in reading recount text by using directed reading activity method at the eighth grade of smp negeri 4 , 
Tapanuli Journals, 1(2),2622-8823.

Jacobson, E., \& Ianiro, S. (2007). Reading comprehension : research and teaching strategies. Reasearch Digest No. 8, (2004), 0-3.

Jonson, K.F. (2006). 60 Strategies for improving reading comprehension in Grades K-8. California: Corwin Press a SAGE Publications Company.

Lodico, M.G. et al. (2010). Methods in educational research from theory to practice second edition. San Fransisco: Jossey-Bass.

Lubis, Y. (2018). The effect of drta teaching strategy and learning style on students' achievement in reading comprehension at faculty of tarbiyah science and teacher training state islamic university of north sumatra. VISION: Journal of Language, Literature \& Education, 13(13), 1-27.

Manzo, A.V., \& Ula, C.M. (1995). Teaching children to be literate: a reflective approach. Orlando: Harcourt Brace Collage Publisher.

Richards, J. C., \& Schmidt, R. (2002). Longman dictionary of language teaching and applied linguistics, third edition. London: Pearson Education Limited.

Richardson, J. S., \& Morgan, R. F. (2009). Reading to learn in the content areas seventh edition. Belmont, CA: Wadsworth Publishing Company.

Roe, Betty. D \& Sandy H.Smith (2012). Teaching reading in today's elementary school, eleventh edition. Canada: Wadsworth CENGAGE Learning.

Sari, L. (2017). Improving reading comprehension through directed reading thinking activity ( drta ) strategy for the eight grade students of smp negeri 17 medan in the academic year of 2016-2017, Thesis. Medan: UIN-SU Medan.

Stauffer, R.G. (1969). Directing reading maturity as a cognitive process. New York, NY: Harper and Row.

Willingham, D. T. (2007). Critical Thinking why is it so hard to teach?. Journal of Psychological Science, 7, 337-342.

Yazdani, M. M., \& Mojtaba, M. (2015). The explicit instruction of reading strategies: directed reading thinking activity vs guided reading strategies, International Journal of $\begin{array}{llll}\text { Applied Linguistics \& English } & \text { Literature, }\end{array}$ https://doi.org/10.7575/aiac.ijalel.v.4n.3p.53

Zohar, A., \& Dori, Y. J. (2003). Higher order thinking skills and low-achieving students : are they mutually exclusive?, The Journal of the Learning Sciences, 12(2), 145-181. 